\title{
QUANTITATIVE AND VISUALIZED INTERPRETATION OF PUBLIC WORKS CIVIL LITIGATION SCENARIO OF FIRST INSTANCE REVIEW IN TAIWAN
}

\author{
Hsien-Sang Wu \\ Department of Civil Engineering, National Central University, Chung Li 32011, Taiwan, R.O.C., s338838@kcg.gov.tw \\ John Chien-Chung Li \\ Department of Civil Engineering, National Central University, Chung Li 32011, Taiwan, R.O.C. \\ Jeng-Rong Lee \\ Department of Construction Engineering, National Kaohsiung First University of Science and Technology, Kaohsiung \\ 81148, Taiwan, R.O.C. \\ Wen-Yen Wu \\ Department of Public Policy and Management, I-Shou University, Kaohsiung 84001, Taiwan, R.O.C.
}

Follow this and additional works at: https://jmstt.ntou.edu.tw/journal

Part of the Civil and Environmental Engineering Commons

\footnotetext{
Recommended Citation

Wu, Hsien-Sang; Li, John Chien-Chung; Lee, Jeng-Rong; and Wu, Wen-Yen (2011) "QUANTITATIVE AND VISUALIZED INTERPRETATION OF PUBLIC WORKS CIVIL LITIGATION SCENARIO OF FIRST INSTANCE REVIEW IN TAIWAN," Journal of Marine Science and Technology. Vol. 19: Iss. 2, Article 11.

DOI: $10.51400 / 2709-6998.2154$

Available at: https://jmstt.ntou.edu.tw/journal/vol19/iss2/11

This Research Article is brought to you for free and open access by Journal of Marine Science and Technology. It has been accepted for inclusion in Journal of Marine Science and Technology by an authorized editor of Journal of Marine Science and Technology.
} 


\title{
QUANTITATIVE AND VISUALIZED INTERPRETATION OF PUBLIC WORKS CIVIL LITIGATION SCENARIO OF FIRST INSTANCE REVIEW IN TAIWAN
}

\author{
Hsien-Sang $\mathrm{Wu}^{*}$, John Chien-Chung $\mathrm{Li}^{*}$, Jeng-Rong Lee**, and Wen-Yen $\mathrm{Wu}^{* * *}$
}

Key words: public works, civil litigation, log-linear analysis, multiple correspondence analyses.

\begin{abstract}
Existing studies regarding public works disputes and claims have drawn on small-scale cases to the exclusion of other cases and few have met the requirements of statistical tests. This paper performs an investigation of a total of 400 cases of civil litigation in which owners lost their disputes in Taiwan High Courts and branches between 1999 and 2008. Category analysis coding is used to construct a Log-linear model for judgment decisions; this model is augmented by Multiple Correspondence Analysis to reduce judicial opinions of over 4 million words to a two-dimensional figure, allowing for visual interpretation and identifying specific cases for future examination. The primary findings were: (1) the Government Procurement Law has contribute to shortening litigation times; (2) professional engineering agencies are easily involved in lawsuits, (3) the First-Instance judgments affirmed rate by High Courts is $52.38 \%$; (4) the rejection of the First Instance review of court houses in different regions are different.
\end{abstract}

\section{INTRODUCTION}

The construction dispute is an ancient issue, probably since the time of Hammurabi Code [7] or even earlier. Nowadays, these issues have increasingly been a common social phenomenon in public works, and contribute to a major portion to legal practice $[16,24]$.

Because of the continuous nature of legal relationship of

Paper submitted 10/30/09; revised 03/08/10; accepted 03/17/10. Author for correspondence: Hsien-Sang Wu (e-mail: s338838@kcg.gov.tw).

*Department of Civil Engineering, National Central University, Chung Li 32011, Taiwan, R.O.C.

**Department of Construction Engineering, National Kaohsiung First University of Science and Technology, Kaohsiung 81148, Taiwan, R.O.C.

***Department of Public Policy and Management, I-Shou University, Kaohsiung 84001, Taiwan, R.O.C. each construction contract, the participants have anticipated on amicability of both sides to seek for efficiency during the delivery process. However, contractual dispute happens frequently. It is well-known that litigation is the most inefficient and adversarial method for the projects' dispute resolution. In order to avoid lawsuits, there were so many papers discussing the various Alternative Dispute Resolution (ADR) mechanisms in the past decades [5, 6, 8, 9, 12, 13, 15, 20, 37].

In virtue of statutory obligation of civil servants and characteristics of public works in opposition to supervision mechanisms, the procurement agencies always succumb to the conservative baseline [41].

The ADR results may sometimes not binding, thus leave the disputes unresolved. It is the purpose of this study to compile the litigation cases collected from the First Instance review and to analyze statistically for establishing the common resolutions toward various types of disputes.

The common resolutions established may be used to help accelerate achieving final resolutions in the future ADR cases. It was also considered to use the resolved ADR cases to enlarge the bases for analyses. However, due to the confidentiality requirement of $\mathrm{ADR}$ cases, the raw data was difficult to obtain [38]. Therefore, the ADR cases were not adopted.

Contracts of typical public works follow a uniform pattern, thus the ability to actively improve the contract delivery really remains with the contracting agency's attitude. The private entities in the construction industry have behavioral factors e.g. opportunism to consider [39, 40].

It is, therefore, worthwhile citing judicial cases that governmental agencies lost because the government agencies' may have been wrong in the contract delivery process, that could serve as good examples to help both parties to evaluate the possibility to win, especially the government side, and to make proper decisions to promote reconciliation between both sides.

The legal system of Taiwan succeeds Roman law, The Supreme Court, High Courts, including their branches and the District Courts are established to hear and decide civil and criminal cases. The "three-level and three-instance" system is the basic structure. The fact review on the issues are carried out at trials in both the First and the Second instances, while 


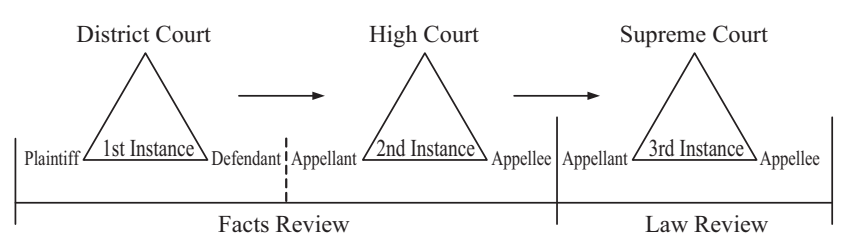

Fig. 1. Taiwan's instance levels of judicial system.

trials of the Third instance consider only issues of law, shown as Fig. 1 [26]. Thus the factual judgments are achieved in the first two instances. Due to the limited time and effort involved, only the 400 cases judged in the past 10 years in the Second Instances are used in this study.

Similar researches $[14,23]$ have been conducted before. However, in the previous studies, it was acknowledged the weakness of intuitive sampling, and the inconsistency with the statistic test. The sample size in this study has been increased largely and the analyses consistent with statistic test.

\section{DATA COLLECTION}

According to Article 31 in Chapter III of Taiwan's Court Organization Act and the administrative organization system of the Judicial Yuan, this study limits its research to the Taiwan High Court and its branches, including the Taichung branch, the Tainan branch, the Kaohsiung branch, and the Hualien branch. Moreover, also includes the Fujian High Court and the Kinmen branch.

Litigants are both parties of the construction contract. In this case, the construction contract party files a lawsuit with the District Court. After the respective court of First Instance delivers a judgment, the plaintiff, the defendant, or both parties can file a Second Instance appeal to the High Court (or its branches) if not satisfied with the First Instance judgment.

The source for the text of the Second Instance decision of the related litigation cases in this study came from the verdict available on the website of the Judicial Yuan. Following the dialog window of the database, the research entered the query criteria. The key words were project payments and damage compensation. It is searched for judicial opinions from High Courts and branches between 1999 to 2008 period in which the public sector had the ability for active improvement and in which agencies lost.

This search yielded a total of 400 cases. The screening criteria of the agencies losing the case disregarded whether the plaintiff was the procurement agency or the firm. In the text of the Second Instance decision, except that the High Court (or its branches) determined the firm's statements were groundless and overruled the cases, all the agencies were considered to lose the cases if there were any reasons attributable to the procurement agencies, even if damages ordered by the courts of First and Second Instance were different.

The research raw data as mentioned above through comprehensive literature reviews $[19,21,28-30,32-34]$ and

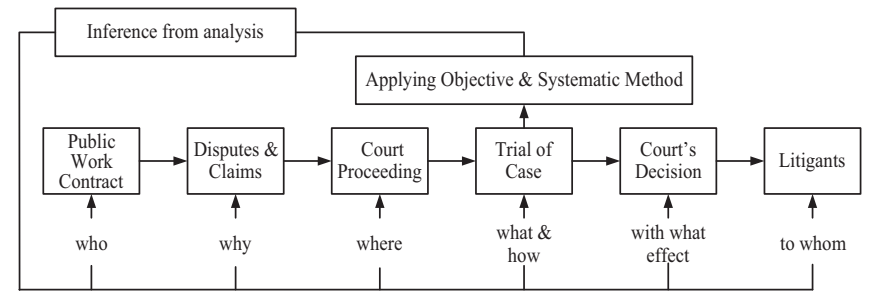

Fig. 2. Transmission models of communication.

based on the transmission models of communication developed by Lasswell according to the framework of "Who said what in what manner, and what effect was produced?" [22] as shown in Fig. 2, characteristics displayed by contested works, e.g. parties to contractual elements, causes of action for suing, litigation time consumption, and claim ratio (ratio of claim amounts and contract amounts), were extracted, i.e., selected as variables for analysis from 400 cases.

The raw data had already excluded $5 \%$ of extreme values, i.e., maximums and minimums. Relevant discrete variable data was changed into logarithmic normal distribution through smoothing [4], e.g. litigation time consumption 21 years changed into $\log 21 \fallingdotseq 1.322$.

The material for this study was derived from the judicial opinions from Second fact review rendered by High Courts and branches which are intended to resolve the judicial opinions rendered by District Courts in First facts review in public works civil litigation cases.

The categorization process does not include response variables or explain distinctions between variables; all variables are viewed as responses together. Using the principle of category simplification, each variable level is given coding as a basis for computer calculation and analysis [3, 27].

See Table 1 for explanations and abbreviations of codes for selected variables. According to the principle of no trial without complaint, the plaintiff in the First Instance is used as a core to perform the Chi-square test. Variables and plaintiffs for which chi-square test results demonstrated significant correlation $(P<0.05)$ are shown in Table 2 (This paper adopted $P$-Value method and set significance $\alpha=0.05)$.

From Table 2, it is found that there were 7 variables reached significant level with plaintiff; however, the associations between these variables were still unknown.

\section{RESEARCH METHODS}

The purposes of the two different methods applied in this research design were: (1) applying Log-linear analysis in exploring the interaction between variables to set a model. A parsimonious model explaining District Court's First Instance results was found. Specific data was substituted for the descriptive results described as "normal" in previous research, thereby correcting the shortcoming of a lack of statistical testing in previous studies; (2) involving Multiple Correspondence Analysis (MCA) and using graphical augmentation to 
Table 1. Explanation of codes for selected variables.

\begin{tabular}{|c|c|c|}
\hline Variables & Coding & Basis for Categorization \\
\hline Claim Type (CT) & $1=$ Payment, 2 = Damage & Court judicial opinion \\
\hline Government Procurement Law (GPL) & $\begin{array}{l}1=\text { Before taking effect, } 2=\text { After taking } \\
\text { effect }\end{array}$ & GPL date of effectiveness (i.e. 27 May 1999) \\
\hline Plaintiff (PLT) & $1=$ Agency, $2=$ Contractor & Primary parties in contract disputes \\
\hline First Instance loser (Lost) & $1=$ Plaintiff, $2=$ Defendant, $3=$ Both & Court judicial opinion \\
\hline Court Location (CL) & $\begin{array}{l}1=\text { Northern, } 2=\text { Mid, } 3=\text { Southern, } 4= \\
\text { Eastern and outlying islands }\end{array}$ & $\begin{array}{l}\text { Geographic locations of Taiwan High Courts and } \\
\text { District Courts }\end{array}$ \\
\hline Time Consumed (TC) & $1=$ Longer, $2=$ Quicker & Average logarithm of 400 cases after smoothing \\
\hline Claim Ratio (CR) & $1=$ Large, $2=$ Small & Average logarithm of 400 cases after smoothing \\
\hline Appellant (APL) & $1=$ Plaintiff, $2=$ Defendant, $3=$ Both & Court judicial opinion \\
\hline $\begin{array}{l}\text { Decision Amount Comparison between first } \\
\text { and second trials (DAC) }\end{array}$ & $1=$ Increase, $2=$ Same, $3=$ Reduce & Court judicial opinion \\
\hline $\begin{array}{l}\text { Decision Result Comparison between first and } \\
\text { second trials (DRC) }\end{array}$ & $\begin{array}{l}1=\text { Non-Different, } 2=\text { Different, } 3= \\
\text { Partial Different }\end{array}$ & Court judicial opinion \\
\hline $\begin{array}{l}\text { Reached Rate of Claim Ratio in 1st Instance } \\
\text { (RRCR1) }\end{array}$ & $1=$ Satisfied, $2=$ Dissatisfied & Average logarithm of 400 cases after smoothing \\
\hline $\begin{array}{l}\text { Reached Rate of Claim Ratio in 2nd Instance } \\
\text { (RRCR2) }\end{array}$ & $1=$ High, $2=$ Low (average of 400 cases) & Average logarithm of 400 cases after smoothing \\
\hline Project Scale (PS) & $1=$ Mega, $2=$ Medium, $3=$ Normal & Definition of Government Procurement Law \\
\hline Project Property (PP) & $\begin{array}{l}1=\text { Civil }, 2=\text { Architecture, } 3=\text { Hydraulic, } \\
4=\text { Facility and other }\end{array}$ & Related pilot study results \\
\hline Agency Level (AL) & $1=$ Central, $2=$ Local & Government organization framework \\
\hline Agency Profession (AP) & $\begin{array}{l}1=\text { Engineering } \\
2=\text { Non-Engineering }\end{array}$ & Engineering discipline \\
\hline Law Quoted (LQ) & $1=$ Procedural, $2=$ Substantive, $3=\mathrm{P} \& \mathrm{~S}$ & Based on current legal categorizations \\
\hline
\end{tabular}

Table 2. First Instance variable correlation Chi-Square test.

\begin{tabular}{|c|c|c|c|c|}
\hline & Chi-Square & d.f. & P & Significance \\
\hline PLT * CT & 74.000 & 1 & .000 & $* * *$ \\
\hline PLT * GPL & 8.323 & 1 & .004 & $* *$ \\
\hline PLT * Lost & 6.115 & 2 & .047 & $*$ \\
\hline PLT * CL & 18.650 & 3 & .000 & $* * *$ \\
\hline PLT * TC & 10.698 & 1 & .001 & $* * *$ \\
\hline PLT * CR & 10.396 & 1 & .001 & $* *$ \\
\hline PLT * AP & 8.764 & 1 & .003 & $* *$ \\
\hline \multicolumn{6}{|c|}{ Significance: *<.05, **<.01, ***<.001 } \\
\hline
\end{tabular}

present data analysis results. The contribution of vector points provided by the MCA "Quality" method were used as an objective basis for later selection of individual cases.

\section{Log-Linear Parsimonious Model}

Log-linear analysis is a categorical variable analysis method commonly used in English-language social sciences research. It is highly appropriate for analysis of multidimensional contingency tables, particularly for unknown interactions between variables. Traditionally, the strength of association for categorical data is determined through the independent signifi- cance between variables according to the Chi-Square test. However, the Chi-Square test can only process the relationship between two variables at once and cannot provide further research information when faced with interaction between three or more variables. Log-linear analysis uses a method similar to Chi-Square analysis to test for the strength of association between two or more variables in multi-way contingency tables and to resolve variable combination models involving interaction $[2,10]$. Log-linear models take the natural logs of the observed frequency in contingency tables, equivalent to the constant term mu (grand mean) plus the parameter estimates lambda $(\lambda)$ of orders with interaction. A two-level saturated model is used for explanation, as shown in Eq. (1).

$$
\ln \left(O_{i j}\right)=\mu+\lambda_{i}^{A}+\lambda_{j}^{B}+\lambda_{i j}^{A B}
$$

The term denoted as $O_{i j}$ in Eq. (1) represents the observed frequency; $i$ and $j$ are the numbers in the contingency table and in rows; $\lambda^{A B}$ is the 2 nd order interactions between variables $\mathrm{A}$ and $\mathrm{B}$. When a high-order $\lambda^{A B}$ interaction exists, the lowerorder $\lambda^{A}$ and $\lambda^{B}$ necessarily exist. The sum of the main effects of individual variables is 0 . In the same way, the sum of the interactions between variables must also be 0 . Two items in log-linear analysis must be satisfied ahead of time. First, the 
frequency of observed values in each cell must be mutually independent, meaning that measurement of each nominal variable is only performed once; each observed value only makes one response. Then, based on practical analytical experience, the frequency in each cell cannot be less than 5 in order to prevent errors occurring due to low expected frequency. Cochran (1954) pointed out that the expected frequency should be greater than 5 for $80 \%$ of cells and the expected frequency for any cell can not be lower than 1 . When performing log-linear model analysis, the expected frequency for each cell is calculated as in Chi-Square testing; the calculation equation is as shown in Eq. (2).

$$
E_{i j}=\frac{O_{i+} O_{j+}}{O_{++}}
$$

The term denoted as $E_{i j}$ in Eq. (2) represents the expected frequency. It can be obtained from Eq. (2) that the expected frequency of any cell is equivalent to the marginal total corresponding to the cells multiplied by each other and then divided by the total frequencies. The Chi-Square value $x^{2}$ can be calculated based on expected frequency as shown in Eq. (3) below.

$$
x^{2}=\sum_{i=1}^{I} \sum_{j=1}^{J} \frac{\left(O_{i j}-E_{i j}\right)^{2}}{E_{i j}}
$$

Expected frequency is a multiplicative model and requires conversion of logarithms into linear models, as shown in Eq. (4).

$$
\ln E_{i j}=\ln \left\{\frac{O_{i+} \times O_{+j}}{O_{++}}\right\}=\ln O_{i+}+\ln O_{+j}-\ln O_{++}
$$

The log-linear model uses the maximum probability method to estimate the goodness of fit for the model. Consequently, the likelihood ratio statistic $G^{2}$ is substituted for Chi-Square statistic $x^{2}$ in performing hypothesis testing. $G^{2}$ is divisible and is capable of individually testing the goodness of fit for different models. When a study involves a large sample, the $G^{2}$ value approximates Chi-Square distribution, and its degree of freedom (df) is the number of parameter estimates subtracted from the number of cells; significance testing is performed using this figure as a basis. The calculation equation is as shown in Eq. (5).

$$
G^{2}=2 \sum_{i} \sum_{j}\left(O_{i j}\right) \ln \left(\frac{O_{i j}}{E_{i j}}\right)
$$

Simply put, log-linear analysis is intended to construct a parsimonious model with no significant difference from the saturated model. The steps of log-linear analysis are: (1) model selection and general log linear checking; (2) parameter estimate and model resolution.

\section{Model Selection and Checking}

Model selection typically involves the use of the hierarchical model method. This study uses SPSS statistics software version 13.0 as an analytical tool. Model selection steps are explained based on SPSS statistics software computation and output rules:

Step 1: Use Eq. (5) to calculate the $G^{2}$ of each model for goodness of fit testing. If the $\mathrm{G}^{2}$ value of a model meets significant levels, then the model is not a good fit. If the $G^{2}$ of only one model does not reach significant levels, then that model is the best fit model.

Step 2: If the $G^{2}$ values of two or more models do not reach significant levels, then the model with the lowest $G^{2}$ value is the better fit model.

Step 3: Based on the better fit model selected in Step 2, use the divisibility of $G^{2}$ and the high-order model of the same order as the model to select the fit model with the lowest $G^{2}$; use this model as a basis for further SPSS statistics software General Log Linear function checking.

\section{Parameter Estimates and Interaction Measurement}

After finding a best fit model, further parameter estimating is done for those cells which reach significant levels based on the model. The parameter estimates here can be termed odds. Odds are defined as the probability of some event occurring divided by the probability of occurrence for an opposing event, as in Eq. (6). The term odds ratio refers to the ratio between two odds. An odds ratio can be any non-negative value, reflecting association on both sides of 1 . A value further away from 1 in any given direction represents a stronger association. When the odds ratio $=1$, because $\mathrm{e}^{(0)}=1$, if the existence of a 0 value is included within the $95 \%$ confidence interval level, then the variables in question are statistically independent and there is no interaction effect between them. It is possible to measure the size of interaction between variables through odds ratios and parameter estimates in parsimonious models with goodness of fit for cells. Log-linear analysis typically uses standardized parameter estimates as a standard for measurement. SPSS statistics software outputs are labeled $Z$; standardized parameter estimates are the quotients of parameter estimates divided by standard errors, as shown in Eq. (7). The magnitude of the absolute value of $Z$ shows the relative importance between two cells in a contingency table. As $|Z|>$ 1.96, the significance has been reached. As software output results are logarithms, it is appropriate to restore a logarithm after extracting an index for resolution $[31,35]$.

$$
\begin{gathered}
\text { Odds }=e^{(\text {estimate })} \\
Z=\text { estimate/std.error }
\end{gathered}
$$




\section{Multiple Correspondence Analyses}

Visualized description is a powerful auxiliary tool that can provide categorical analysis in the form of results presented as numerical figures. Correspondence analysis (CA) is one of these methods. CA has been continually developed into many different forms and versions. Current knowledge of CA in the scientific world is owed largely to the graphical methods particularly emphasized by French mathematician Jean-Paul Benzécri. In dismissing statistical meaning and making considerations in terms of the geometric definitions of principal component analysis (PCA), CA can be viewed as a PCA for categorical data. Rows and columns in data matrices are set as points in a high-dimensional Euclidean space. The purpose is to re-define spatial dimensions and to extract the vast majority of possible variations, then to project the results into lowdimensional spatial graphic, visually interpreting complex original data structures [11].

As a result, CA is often considered to be a model-free method; in addition, there are no excessive limiting conditions and hypothetical premises in combining $\mathrm{CA}$ and log-linear analysis. CA primarily applies $2 \times 2$ contingency tables to graphically express relationships between two categorical variables. CA can provide the following information: (1) relationships between variables: in terms of graphics with factor axes as coordinates, neighboring variable points show that these variables are tightly correlated; (2) relationships between sample points: neighboring sample points have similar properties and belong to the same category; (3) relationships between variables and samples: sample points of the same type will be explained by neighboring variables. CA can display excellent graphics, visually augmenting resolution [17]. The difference between MCA and CA is in that MCA is used to process $\mathrm{CA}$ with two or more variables.

Multiple correspondence analyses (MCA) primarily codes multivariate category data into indicator matrix or Burt matrix formats. The most classical and standard practice of MCA is applying the indicator matrix $\mathrm{Z}$ of simple CA for calculation. Indicator matrix $\mathrm{Z}=\{\mathrm{Zij}\}$ is a binary coding factor, replacing one Jq-level factor, which can also be termed a dummy variable with the binary code of a Jq column. Calculation of indicator matrices involves normalization conversion of a contingency table into a probability table and seeking two-dimensional plane vectors (factor axes) and factor points (coordinates) of average row or column profiles through standardization residual matrix calculations and singular value decomposition (SVD) processes; the coordinates of cells, also termed profile points, projected onto a two-dimensional plane are sought after. Through the relationships between ChiSquare distance explanation variables of profile points and variables or sample points, Pearson's Chi-Square value is used to check the association between variables. When the data is multidimensional uses eigenvalue as a standard for inertia explanatory power. Calculation steps are described below $[1,18]$.

If there are $\mathrm{K}$ nominal scale variables, each nominal scale variable has $J k$ grade levels, where $\Sigma J k=\mathrm{J}$ exists. If there are I observed values, then $\mathrm{I} \times \mathrm{J}$ indicator matrix is expressed in matrix $\mathrm{X}$. The grand total of the matrix table is explained by $\mathrm{N}$ :

(1) Normalize the original data matrix and calculate the probability matrix $Z=N^{-1} X$, causing $r$ to represent the marginal total vectors of rows, or row masses, in matrix Z. c is the column marginal total vector, or column masses, of matrix $Z$. Cause $\operatorname{Dr}=\operatorname{diag}\{r\}, D c=\operatorname{diag}\{c\}$, which each represents a matrix with row mass or column mass as diagonals.

(2) Solve for outliers. Singular value decomposition (SVD) can be used to solve factor scores. Eigenvalues are as in Eq. (8) below: In Eq. (8), is a standardized residuals matrix; represents a matrix with outliers as diagonals; is the eigenvalue matrix;

$$
\mathbf{D r}^{-1 / 2}\left(\mathbf{Z}-\mathbf{r c}^{\mathrm{T}}\right) \mathbf{D}_{\mathbf{c}}^{-1 / 2}=\mathbf{P} \Delta \mathbf{Q}^{\mathrm{T}}
$$

(3) Solve for the factor points (coordinates) of rows and columns, respectively, using the following equations:

$$
\mathbf{F}=\mathbf{D r}_{\mathbf{r}}^{-1 / 2} \mathbf{P} \boldsymbol{\Delta} \text { and } \mathbf{G}=\mathbf{D}_{\mathbf{c}}^{-1 / 2} \mathbf{Q} \Delta
$$

(4) Calculate Chi-square distance; Chi-square distance from row and column profiles to Barry centers is calculated as below:

$$
\mathbf{D}_{\mathbf{r}}=\operatorname{diag}\left\{\mathbf{F F}^{\mathbf{T}}\right\} \text { and } \mathbf{D}_{\mathbf{c}}=\operatorname{diag}\left\{\mathbf{G G}^{\mathbf{T}}\right\}
$$

(5) Calculate the squared cosine of row $i$ and factor $l$ and of column $j$ and factor $l$; these are the explanatory power of factor axes for profiles; they can be solved as follows: In these equations, $\mathbf{d}_{\mathbf{r . i}}^{2}$ and $\mathbf{d}_{\mathbf{c}, \mathbf{j}}^{2}$ respectively represent the $i^{\text {th }}$ element of $d_{\mathrm{r}}$ and the $j^{\text {th }}$ element of $d_{c}$. Square-related assistance marks important factors for observed values or variables.

$$
\mathbf{O}_{\mathrm{i}, \mathrm{I}}=\frac{\mathbf{f}_{\mathrm{i}, \mathrm{I}}^{2}}{\mathbf{d}_{\mathrm{r}, \mathrm{i}}^{2}} \text { and } \mathbf{O}_{\mathrm{j}, \mathrm{I}}=\frac{\mathbf{g}_{\mathrm{j}, \mathrm{I}}^{2}}{\mathbf{d}_{\mathrm{c}, \mathrm{j}}^{2}}
$$

(6) Calculate the explanatory power of profiles for factor axes, or the contribution of row $i$ towards factor 1 as well as the contribution of column $j$ towards factor 1 ; these can be solved using the following equations: The contribution value assistance of points towards factor axes marks important observed values or variables for known factor axes and provide a reference for the naming of factor axes, assisting in explaining the structural relationships of variables.

$$
t_{i, l}=\frac{J_{i, l}^{2}}{\lambda_{l}} \text { and } t_{j, l}=\frac{g_{j, l}^{2}}{\lambda_{l}}
$$


Application of the SPSS13.0 can provide the parameters needed for MCA and still provide Chi-square test values [36].

\section{STATISTICAL ANALYSIS AND VISUALIZED INTERPRETATION}

For District Court judgments on contract disputes, according to the Chi-square test results shown in Table 2, a total of 7 variables showed significant correlation with First fact review plaintiffs. Based on rational logic, these variables can be divided into two different stages: (1) litigation preparation; (2) filed a suit. Relevant output reports are resolved as follows:

\section{Model Selection and Checking in the Litigation Preparation Stage}

The highest-order model of the litigation preparation stage is of the 4th order (i.e. saturated model), comprising interaction between \{plaintiff * procurement law $*$ litigation time consumption * institution expertise * $\}$. The $G^{2}$ values of the 4th order and 3rd order models were 0.60 and 4.655. After removing the 4 th order model, the $G^{2}$ value was reduced by only 0.60 ; the $\mathrm{P}$ value was $0.8072>0.05$, showing no significant difference from the saturated model, meaning that there is a poor goodness-of-fit. After removing the $3 \mathrm{rd}$ order model, the $G^{2}$ value only $4.655-0.06=4.595$. The significant level $\mathrm{P}$ value was $0.3314>0.05$, indicating a poor goodness of fit. Conversely, the $G^{2}$ value of the 1 st order model was 389.159 and the $G^{2}$ value of the 2nd order model was 115.383; the difference between the two indicates that the contribution of the 1 st order model was 273.776 . Following the same logic, the difference between the $G^{2}$ values of the 2nd and 3rd order models indicates that the contribution of the 2 nd order model was 110.728 and that the $P$ value was equal to 0 . Consequently, the 1st order and 2nd order models are retained, as in Tables 3 and 4. A total of 10 incremental screenings were performed through hierarchical backward elimination to determine that three 2nd order models with good goodness of fit were \{plaintiff * litigation time consumption\}, \{procurement law * litigation time consumption\}, and \{plaintiff * institution expertise $\}$. Further calculation using the general log linear function of SPSS demonstrated that the P values of the saturated model and completely independent models had reached significant levels, showing that the models had poor goodness of fit. The $\mathrm{P}$ value of the $2 \mathrm{nd}$ order conditional independent model is grater than 0.05 , suggesting a model with goodness of fit, as in Table 5.

\section{Effects Measurement and Interpretation in the Litigation Preparation Stage}

For second fact review cases in which agencies lost, with regard to plaintiffs in the First Instance litigation preparation stage, except for cases in which plaintiffs are professional agencies whose 2 nd order interactions are non-significant, the other 2 nd order interactions reached significant levels. In the interaction between plaintiff and litigation time consumption,
Table 3. $G^{2}$ testing for models in the litigation preparation stage.

\begin{tabular}{|c|c|c|c|c|c|c|}
\hline K & DF & $\begin{array}{c}\text { L.R. } \\
\text { Chisq }\end{array}$ & Prob & $\begin{array}{c}\text { Pearson } \\
\text { Chisq }\end{array}$ & Prob & Iteration \\
\hline 4 & 1 & .060 & .8072 & .059 & .8076 & 2 \\
\hline 3 & 5 & 4.655 & .4595 & 4.643 & .4610 & 5 \\
\hline 2 & 11 & 115.383 & .0000 & 116.12 & .0000 & 2 \\
\hline 1 & 15 & 389.16 & .0000 & 412.83 & .0000 & 0 \\
\hline
\end{tabular}

Table 4. $G^{2}$ differences for models in the litigation preparation stage.

\begin{tabular}{|c|c|c|c|c|c|c|}
\hline K & DF & $\begin{array}{c}\text { L.R. Chisq } \\
\text { Change }\end{array}$ & Prob & $\begin{array}{c}\text { Pearson } \\
\text { Chisq } \\
\text { Change }\end{array}$ & Prob & Iteration \\
\hline 1 & 4 & 273.776 & .0000 & 296.708 & .0000 & 0 \\
\hline 2 & 6 & 110.729 & .0000 & 111.479 & .0000 & 0 \\
\hline 3 & 4 & 4.595 & .3314 & 4.584 & .3327 & 0 \\
\hline 4 & 1 & .060 & .8072 & .059 & .8076 & 0 \\
\hline
\end{tabular}

Table 5. Goodness of fit for models in the litigation preparation stage.

\begin{tabular}{|c|c|c|c|c|c|}
\hline Model & $\mathrm{G}^{2}$ & $\mathrm{P}$ & $\mathrm{x}^{2}$ & $\mathrm{P}$ & $\mathrm{DF}$ \\
\hline Saturated & .00 & - & .00 & - & 0 \\
\hline $2^{\text {nd }}$ order conditional & 10.15 & .255 & 10.36 & .241 & 8 \\
\hline Completed independent & 115.38 & .000 & 116.12 & .000 & 11 \\
\hline
\end{tabular}

$\{\mathrm{PLT}=2 * \mathrm{TC}=2\}$ is setting equal 0 as a standard for comparison. In order, the $\mathrm{Z}$ value of $\{\mathrm{PLT}=1 * \mathrm{TC}=1\}=-9.537$; the odds ratio $=\mathrm{e}^{-2.792}=0.06$. The $95 \%$ confidence interval $=$ $\mathrm{e}^{(-3.365 、-2.218)}=(0.034,0.11)$; its upper and lower limits do not include $\mathrm{e}^{0}=1$. Accordingly, null hypotheses with effects of 0 are removed (analogous processes are not described below). The $\mathrm{Z}$ value of $\{\mathrm{PLT}=2 * \mathrm{TC}=1\}=-8.539$; the odds ratio $=$ $\mathrm{e}^{-1.826}=0.16$; its $95 \%$ confidence interval $=\mathrm{e}^{(-2.47-1.425)}$. In other words, odds ratios for cases in which contractors filed for claims and which consume a relatively longer amount of time are 2.67 times those of cases in which agencies filed as shown in Table 6.

Cases in which agencies filed and which take a relatively short amount of time have odds ratios approximately 2.33 times those of cases which take a longer amount of time. When the parameter estimates of $\{\mathrm{PLT}=2 * \mathrm{AP}=2\}$ are set as a basis for comparison, the $\mathrm{Z}$ value of PLT $=2 * \mathrm{AP}=1$ is equal to 3.784 and possesses positive association; the odds ratio $=\mathrm{e}^{0.415}=1.51$, indicating that cases in which contractors filed have odds ratios $51 \%$ higher in cases brought against procuring agencies with engineering professionals than in cases brought against procuring agencies without engineering professionals. The upper and lower limits of the $95 \%$ confidence interval $=\mathrm{e}^{(0.2 \cdot 0.63)}$. 
Table 6. 2nd order parameter estimates in the litigation preparation stage.

\begin{tabular}{|c|c|c|c|c|c|c|}
\hline \multirow{2}{*}{ Parameter } & \multirow{2}{*}{ Estimates } & \multirow{2}{*}{$\begin{array}{l}\text { Std. } \\
\text { Error }\end{array}$} & \multirow{2}{*}{ Z } & \multirow{2}{*}{ Sig. } & \multicolumn{2}{|c|}{$\begin{array}{c}95 \% \text { Confidence } \\
\text { Interval } \\
\end{array}$} \\
\hline & & & & & $\begin{array}{l}\text { Lower } \\
\text { Bound }\end{array}$ & $\begin{array}{l}\text { Upper } \\
\text { Bound }\end{array}$ \\
\hline Constant & 3.98 & .107 & 37.03 & .00 & 3.770 & 4.191 \\
\hline $\begin{array}{c}\text { [PLT_1] * } \\
\text { [TC_1] }\end{array}$ & -2.79 & .293 & -9.54 & .00 & -3.365 & -2.218 \\
\hline $\begin{array}{c}\text { [PLT_1] * } \\
\text { [TC_2] }\end{array}$ & -1.95 & .266 & -7.31 & .00 & -2.470 & -1.425 \\
\hline $\begin{array}{c}\text { [PLT_2] } \\
\text { [TC_1] } \\
\end{array}$ & -1.83 & .214 & -8.54 & .00 & -2.246 & -1.407 \\
\hline $\begin{array}{c}\text { PLT_2] } \\
\text { [TC_2] } \\
\end{array}$ & 0 (a) & . & . & . & . & \\
\hline $\begin{array}{c}\text { [PLT_1] } \\
\text { [AP_1] }\end{array}$ & -.47 & .285 & -1.65 & .1 & -1.029 & .089 \\
\hline $\begin{array}{c}\text { [PLT_1] }{ }^{*} \\
{\left[\mathrm{AP} \_2\right]}\end{array}$ & 0 (a) & . & . & . & . & \\
\hline $\begin{array}{c}\text { [PLT_2] }{ }^{*} \\
{\left[\mathrm{AP} \_1\right]}\end{array}$ & .415 & .110 & 3.78 & .00 & .200 & .630 \\
\hline $\begin{array}{c}\text { [PLT_2] } \\
\text { [AP_2] } \\
\end{array}$ & 0 (a) & . & . & . & . & \\
\hline $\begin{array}{c}{\left[\mathrm{GPL} 1{ }^{1}{ }^{*}\right.} \\
{\left[\mathrm{TC} \_1\right]}\end{array}$ & 1.609 & .211 & 7.63 & .00 & 1.196 & 2.023 \\
\hline $\begin{array}{c}{\left[\mathrm{GPL} \_1\right]^{*}} \\
{\left[\mathrm{TC} \_2\right]}\end{array}$ & -.491 & .134 & -3.67 & .00 & -.753 & -.228 \\
\hline $\begin{array}{c}{\left[\mathrm{GPL} \_2\right]} \\
{\left[\mathrm{TC} \_1\right]}\end{array}$ & 0 (a) & . & . & . & . & \\
\hline $\begin{array}{c}\text { [GPL_2] } \\
\text { [TC_2] } \\
\end{array}$ & 0 (a) & . & . & r & . & \\
\hline
\end{tabular}

(a): Setting equal 0 for comparison basis.

In the same way, $\{\mathrm{GPL}=2 * \mathrm{TC}=1\}$ is set as 0 , and the interaction $\mathrm{Z}$ of $\{\mathrm{GPL}=1 * \mathrm{TC}=1\}$ is equal to 7.634 ; the odds ratio $=\mathrm{e}^{1.609}=5$; the upper and lower limits of its $95 \%$ confidence interval $=\mathrm{e}^{(1.196 \cdot 2.023)}$, meaning that after the implementation of the Government Procurement Law (GPL), the odds of in time-consuming cases were reduced by a large margin.

$\{\mathrm{GPL}=2 * \mathrm{TC}=2\}$ is set as a basis for comparison, and the interaction $Z$ value of $\{\mathrm{GPL}=1 * \mathrm{TC}=2\}$ was equal to -3.666 ; its odds ratio $=\mathrm{e}^{-0.491}=0.61$; the upper and lower limits of its $95 \%$ confidence interval $=\mathrm{e}^{(-0.753 、-0.228)}$. Simply put, after the implementation of the GPL, odds ratios for shorter litigation was 1.63 times those for shorter litigation prior to the implementation of the GPL. Accordingly, it is concluded that the GPL contributes to shorter litigation time, shown as Table 6 . As the existence of 2 nd order interactions, individual main effects for the four variables of plaintiff, agencies' professional, litigation time consumption, and GPL must also exist. (Due to the limitation of paper's length analogous processes of main effects are not described).
Table 7. G2 testing of district court review stage.

\begin{tabular}{|c|c|c|c|c|c|c|}
\hline K & DF & $\begin{array}{c}\text { L.R. } \\
\text { Chisq }\end{array}$ & Prob & $\begin{array}{c}\text { Pearson } \\
\text { Chisq }\end{array}$ & Prob & Iteration \\
\hline 5 & 6 & .486 & .9980 & .267 & .9966 & 6 \\
\hline 4 & 29 & 14.767 & .9867 & 13.019 & .9953 & 9 \\
\hline 3 & 63 & 59.048 & .6179 & 61.087 & .5448 & 4 \\
\hline 2 & 87 & 167.11 & .0000 & 270.330 & .0000 & 2 \\
\hline 1 & 95 & 1140.4 & .0000 & 2035.000 & .0000 & 0 \\
\hline
\end{tabular}

Table 8. G2 differences for models in the district court review and sentencing stage.

\begin{tabular}{|c|c|c|c|c|c|c|}
\hline $\mathrm{K}$ & $\mathrm{DF}$ & $\begin{array}{c}\text { L.R. } \\
\text { Chisq } \\
\text { change }\end{array}$ & Prob & $\begin{array}{c}\text { Pearson } \\
\text { Chisq } \\
\text { change }\end{array}$ & Prob & Iteration \\
\hline 1 & 8 & 973.354 & .0000 & 1764.70 & .0000 & 0 \\
\hline 2 & 24 & 108.060 & .0000 & 209.240 & .0000 & 0 \\
\hline 3 & 34 & 44.281 & .1115 & 48.068 & .0555 & 0 \\
\hline 4 & 23 & 14.281 & .9185 & 12.752 & .9572 & 0 \\
\hline 5 & 6 & .486 & .9980 & .267 & .9996 & 0 \\
\hline
\end{tabular}

Table 9. Model goodness of fit for district sourts review stage.

\begin{tabular}{|c|c|c|c|c|c|}
\hline Model & G2 & P & x2 & P & DF \\
\hline Saturated & .00 & - & .00 & - & 0 \\
\hline All in 4 way & .00 & 1.000 & .00 & 1.000 & 6 \\
\hline All in 3 way & 14.16 & .991 & 12.81 & .996 & 29 \\
\hline All in 2 way & 59.05 & .618 & 61.21 & .540 & 63 \\
\hline $\begin{array}{c}\text { Conditional } \\
\text { independent }\end{array}$ & 21.15 & .996 & 19.75 & .998 & 41 \\
\hline $\begin{array}{c}\text { Completed } \\
\text { independent }\end{array}$ & 167.11 & .000 & 270.33 & .000 & 87 \\
\hline
\end{tabular}

\section{Models Selection and Checking at Filed a Suit in the District Court Stage}

The log-linear analysis process for the stage in which plaintiffs filed for claims in the District Court stage is identical to the process for model selection and calculation in the litigation preparation stage detailed in section 4.

Examined outputs include: 3rd order, 2nd order, and conditional independent models which were determined to have good goodness of fit included [PLT * CL * CR], [PLT *CL * $\mathrm{CT}],[\mathrm{PLT} * \mathrm{CR} * \mathrm{CT}]$, [Lost $* \mathrm{CL} * \mathrm{CR}$ ], [Lost * CL * CT], and $[\mathrm{CL} * \mathrm{CR} * \mathrm{CT}]$, comprising six 3 rd order and one 2 nd order, [PLT * Lost], good fit models, as shown in Tables 7, 8, and 9.

\section{Effects Measurement and Interpretation at Filed a Suit in the District Court Stage}

The same as above section 2, this section deals with parameter estimates and interaction measurement results in the 
various orders of general log linear. Of the third order standardized parameter estimates that reached significant levels, in comparing the numbers of First Instance payment-type cases and damage compensation-type cases in which agencies lost, the proportion is approximately 50.35:1 in northern areas, 18.38:1 in central areas, and 4.04:1 in southern areas. In comparing the respective quantities of First Instance payment-type cases and First Instance damage compensation-type cases in which contractors lost, the proportion is approximately $27.7: 1$ in northern areas, 1.78:1 in central areas, and 7.43:1 in southern areas. Accordingly, the First Instance loss odds ratio for agencies is approximately 1.82 times that for contractors; the analogous odds ratio in central regions is approximately 1.44; the analogous odds ratio in southern regions is approximately 0.54 .

Damage compensation-type cases in northern areas brought by agencies were approximately 45.24 times more common than payment-type cases brought by agencies; in southern areas, nearly all payment-type litigation was brought by contractors. Approximately $80 \%$ of payment-type litigation in northern areas was classified as small claims cases, as shown in Table 10. The data in Table 11 shows the 2nd order standardized parameter estimates which reached significant levels, including: for First Instance judgments in which agencies lost the sue , payment-type litigation cases were approximately 11.94 times more common than damage compensation-type cases; for First Instance judgments in which contractors lost the sue , payment-type cases were approximately 10.8 times more common than damage compensation-type cases. In other words, the odds ratio for agencies losing First Instance cases compared to contractors losing First Instance cases was approximately 1.11 , meaning that, for public works paymenttype and damage compensation-type civil litigation, Second Instance cases in which contractors lost had an average First Instance affirmed of $52.61 \%$. Simply put, the First Instance judgments of northern, central, and southern District Courts were overturned by High Courts as much as $47.39 \%$ of the time. Damage compensation-type cases brought by agencies were approximately 11.25 times more common than payment-type cases. The vast majority of payment-type cases were brought by contractors, constituting 11.25 times the number of payment-type cases brought by agencies. Accordingly, agencies and contractors were roughly equally represented as plaintiffs in compensation cases.

The test results for the interaction between plaintiffs and claims ratio reached the exact significance of 0.05 ; the lower limit of the $95 \%$ confidence interval was exactly equal to 0 . The observed values of original contingency tables show that: there were cells with frequencies of less than 1 , and over $20 \%$ of the cells had frequencies of less than 5. Consequently, more cases should be collected and added into the range of resolution. As the 2nd order interaction was 0 , of the 3 rd order standardized parameter estimates, [plaintiff * court location * claims ratio] and [plaintiff * claims ratio * cause of action] are not included.
Table 10. 3rd order parameter estimates for district court judgments.

\begin{tabular}{|c|c|c|c|c|c|}
\hline \multirow{2}{*}{ Parameter } & \multirow{2}{*}{ Estimate } & \multirow{2}{*}{ Z } & \multirow{2}{*}{ Sig. } & \multicolumn{2}{|c|}{$\begin{array}{l}\text { 95\% Confidence } \\
\text { Interval }\end{array}$} \\
\hline & & & & $\begin{array}{l}\text { Lower } \\
\text { Bound }\end{array}$ & $\begin{array}{l}\text { Upper } \\
\text { Bound }\end{array}$ \\
\hline Constant & -16.150 & -.013 & .990 & -2506.30 & 2474.03 \\
\hline $\begin{array}{c}{\left[\text { Lost_1 } * \mathrm{CL}_{-} 1\right.} \\
\left.* \mathrm{CT} \_1\right]\end{array}$ & 3.919 & 4.48 & .000 & 2.205 & 5.363 \\
\hline $\begin{array}{c}{[\text { Lost_1 } * \text { CL_1 }} \\
\left.* \mathrm{CT} \_2\right] \\
\end{array}$ & $0(a)$ & . & . & • & . \\
\hline $\begin{array}{c}{\left[\text { Lost_1 } * \mathrm{CL}_{2} 2\right.} \\
\left.* \mathrm{CT} \_1\right] \\
\end{array}$ & 2.911 & 3.51 & .000 & 1.285 & 4.538 \\
\hline $\begin{array}{c}{[\text { Lost_1 } * \text { CL_2 }} \\
* \text { CT_2] }\end{array}$ & $0(a)$ & . & . & . & . \\
\hline $\begin{array}{c}{[\text { Lost_1 } * \text { CL_3 }} \\
* \text { CT_1] }\end{array}$ & 1.395 & 2.78 & .005 & .410 & 2.380 \\
\hline $\begin{array}{c}{[\text { Lost_1 } * \text { CL_3 }} \\
\left.* \mathrm{CT} \_2\right]\end{array}$ & 0 (a) & . & . & & . \\
\hline $\begin{array}{c}{[\text { Lost_2 } 2 \text { CL_1 }} \\
\left.* \mathrm{CT} \_1\right]\end{array}$ & 3.321 & 5.16 & .000 & 2.060 & 4.582 \\
\hline $\begin{array}{c}{[\text { Lost_2 } 2 \text { CL_1 }} \\
* \text { CT_2] }\end{array}$ & 0 (a) & . & . & . & . \\
\hline $\begin{array}{c}{[\text { Lost_2 } 2 \text { CL_2 }} \\
* \text { CT_1] }\end{array}$ & 2.548 & 4.97 & .000 & 1.544 & 3.552 \\
\hline $\begin{array}{c}{[\text { Lost_2 } * \text { CL_2 }} \\
\left.* \mathrm{CT} \_2\right] \\
\end{array}$ & 0 (a) & . & . & . & . \\
\hline $\begin{array}{c}{\left[\text { Lost_2 } * \mathrm{CL} \_3\right.} \\
\left.* \mathrm{CT} \_1\right] \\
\end{array}$ & 2.005 & 4.03 & .000 & 1.030 & 2.980 \\
\hline $\begin{array}{c}{[\text { Lost_2 } 2 \text { CL_3 }} \\
\left.* \mathrm{CT} \_2\right]\end{array}$ & 0 (a) & . & . & . & . \\
\hline $\begin{array}{c}{\left[\mathrm{CT} \_1 * \text { PLT_1 }\right.} \\
* \text { CL_1] }\end{array}$ & -3.812 & -4.86 & .000 & -5.348 & -2.275 \\
\hline $\begin{array}{c}{\left[\mathrm{CT} \_2 * \text { PLT_1 }\right.} \\
* \text { CL_1] }\end{array}$ & 0 (a) & . & . & . & . \\
\hline $\begin{array}{c}{\left[\mathrm{CT} \_1 * \text { PLT_1 }\right.} \\
* \text { CL_3] }\end{array}$ & -19.110 & -14.9 & .000 & -21.608 & -16.610 \\
\hline $\begin{array}{c}{[\mathrm{CT} \text { _2 } * \text { PLT_1 }} \\
* \mathrm{CL} \text { _3] }\end{array}$ & 0 (a) & . & . & & . \\
\hline$\underset{\left.\mathrm{CR} \_1\right]}{\left[\mathrm{CT} \_1 * \mathrm{CL}_{-} 1 *\right.}$ & -1.655 & -2.32 & .021 & -3.056 & -.254 \\
\hline $\begin{array}{c}{\left[\mathrm{CT} \_1 * \mathrm{CL}_{-} 1\right.} \\
\left.\mathrm{CR} \_2\right]\end{array}$ & 0 (a) & & & & . \\
\hline
\end{tabular}

As the existence of 2 nd order interactions, individual main effects for the five variables of lost, court location, plaintiff, claim ratio and claim type must also exist. Due to the limitation of paper's length analogous processes of main effects are not described. In compiling the log-linear analysis results described above, the parameter estimate resolutions of various orders for the two stages of plaintiff litigation preparation and district court review judgment can be combined into associa- 
Table 11. 2nd order parameter estimates for district court judgments.

\begin{tabular}{|c|c|c|c|c|c|}
\hline \multirow[b]{2}{*}{ Parameter } & \multirow[b]{2}{*}{ Estimate } & \multirow[b]{2}{*}{ Z } & \multirow[b]{2}{*}{ Sig. } & \multicolumn{2}{|c|}{$95 \%$ Confidence Interval } \\
\hline & & & & $\begin{array}{l}\text { Lower } \\
\text { Bound }\end{array}$ & $\begin{array}{l}\text { Upper } \\
\text { Bound }\end{array}$ \\
\hline Constant & -30.400 & -.020 & .980 & -2991.30 & 2930.568 \\
\hline $\begin{array}{c}\text { [Lost_1] }{ }^{*} \\
{\left[\mathrm{CT} \_1\right]}\end{array}$ & 2.480 & 2.73 & .006 & .696 & 4.260 \\
\hline $\begin{array}{c}\text { [Lost_1] }{ }^{*} \\
\text { [CT_2] }\end{array}$ & $0(\mathrm{a})$ & . & . & . & . \\
\hline $\begin{array}{c}\text { [Lost_2 }]^{*} \\
{\left[\mathrm{CT} \_1\right]}\end{array}$ & 2.380 & 2.67 & .008 & .630 & 4.130 \\
\hline $\begin{array}{c}\text { [Lost_2] }{ }^{*} \\
{\left[\mathrm{CT} \_2\right]}\end{array}$ & $0(\mathrm{a})$ & . & . & . & . \\
\hline $\begin{array}{c}{\left[\mathrm{PLT} \_1\right]} \\
{\left[\mathrm{CR} \_1\right]}\end{array}$ & .675 & 1.96 & .050 & .000 & 1.349 \\
\hline $\begin{array}{c}\text { [PLT_1] } \\
\text { [CT_1] }\end{array}$ & -2.42 & -6.77 & .000 & -3.124 & -1.722 \\
\hline $\begin{array}{c}\text { [PLT_1] } \\
\text { [CT_2] }\end{array}$ & 0 (a) & . & . & . & $\cdot$ \\
\hline $\begin{array}{c}\text { [PLT_2] } \\
\text { [CT_1] }\end{array}$ & $0(\mathrm{a})$ & . & . & . & . \\
\hline $\begin{array}{c}\text { [PLT_2] } \\
\text { [CT_2] }\end{array}$ & $0(\mathrm{a})$ & . & $\cdot$ & . & $\cdot$ \\
\hline
\end{tabular}

(a): Setting equal 0 for comparison basis.

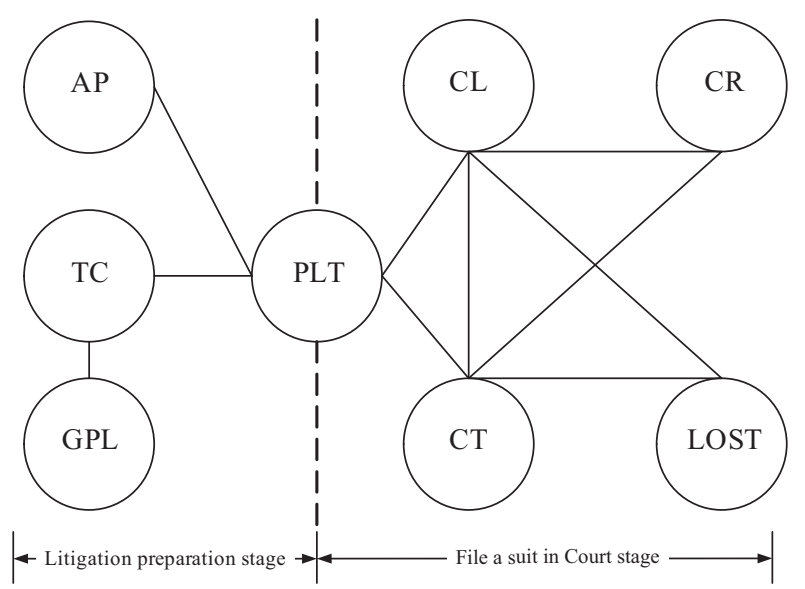

Fig. 3. Public works civil litigation first instance judgment variables associations diagram.

tions of First Instance judgment result variable interaction based on a fitting parsimonious model, as shown in Fig. 3.

\section{Visualized Interpretation of Litigation Preparation Stage}

One must input the litigation preparation stage log-linear parsimonious model described in sec. 2 into SPSS to output an MCA map. Table 12 shown the naming principles for dimensions 1 and 2. Maximum TC and AP are used as discrimi-
Table 12. Discrimination Measures of litigation preparation.

\begin{tabular}{|c|c|c|}
\hline \multirow{2}{*}{} & \multicolumn{2}{|c|}{ Dimension } \\
\cline { 2 - 3 } & 1 & 2 \\
\hline GPL & .592 & .137 \\
\hline PLT & .246 & .234 \\
\hline TC & .632 & .072 \\
\hline AP & .113 & .590 \\
\hline
\end{tabular}

Table 13. Model Summary of litigation preparation.

\begin{tabular}{|c|c|c|}
\hline \multirow{2}{*}{ Dimension } & \multicolumn{2}{|c|}{ Variance Accounted For } \\
\cline { 2 - 3 } & Total (Eigenvalue) & Inertia \\
\hline 1 & 1.583 & .396 \\
\hline 2 & 1.033 & .258 \\
\hline Total & 2.616 & .654 \\
\hline
\end{tabular}

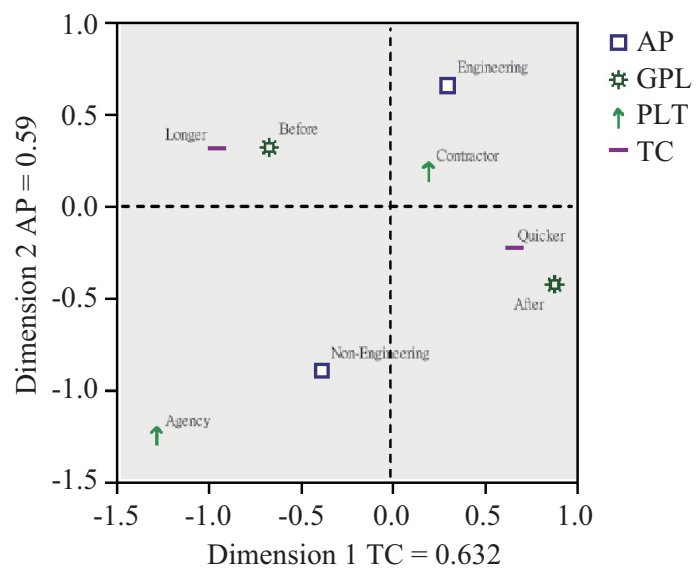

Fig. 4. MCA Map of litigation preparation.

nation measures. The litigation preparation stage MCA map inertia reached $65.4 \%$, as shown in Table 13 .

In the resolution results for the log-linear model displayed on a two-dimensional plot, the interaction relationship between [PLT * AP] was: in cases brought by contractors, the procuring agencies generally had engineering professionals; conversely, sue s filed by agencies generally involved agencies that did not include engineering professionals; in terms of the interaction relationship of [GPL * TC], the length of time consumed in litigation was very clearly distinguished by changes before and after the implementation of the GPL, as shown in Fig. 4.

In 400 specific cases, in the litigation preparation stage, the contribution of dimension to inertia of point ("Quality") was calculated having a mean of 0.67 with a standard deviation of 0.28 according to SPSS software output; the mean plus one standard deviation was used as a degree. A total of 57 cases were litigation cases with high explanatory power, with Quality higher than or equal to 0.95 . This method can provide 
Table 14. Discrimination measures of district court review.

\begin{tabular}{|c|c|c|}
\hline \multirow{2}{*}{} & \multicolumn{2}{|c|}{ Dimension } \\
\cline { 2 - 3 } & 1 & 2 \\
\hline CT & .502 & .054 \\
\hline PLT & .627 & .023 \\
\hline LOST & .119 & .442 \\
\hline CL & .206 & .581 \\
\hline CR & .195 & .001 \\
\hline
\end{tabular}

Table 15. Model summary of district court review.

\begin{tabular}{|c|c|c|}
\hline Dimension & \multicolumn{2}{|c|}{ Variance Accounted For } \\
\hline & Total (Eigenvalue) & Inertia \\
\hline 1 & 1.649 & .330 \\
\hline 2 & 1.101 & .220 \\
\hline Total & 2.750 & .550 \\
\hline
\end{tabular}

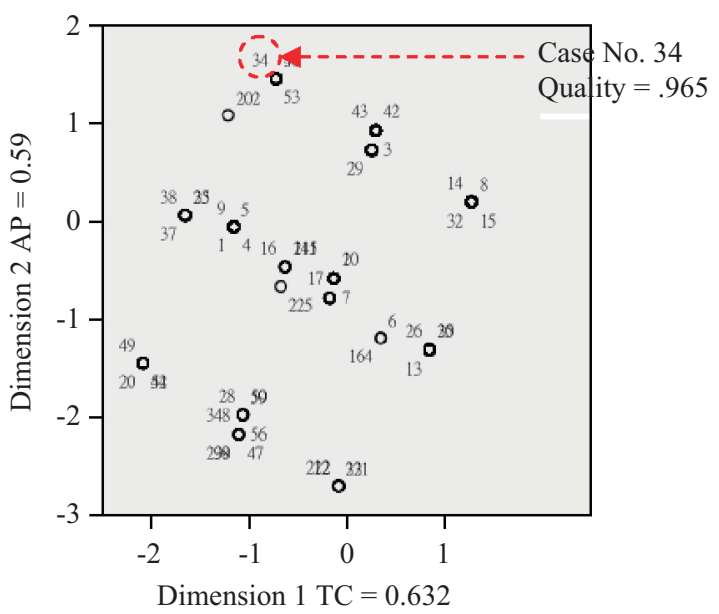

Fig. 5. Objective sample of litigation preparation stage case examination.

an objective basis for sampling in research on litigation preparation stage cases, as shown in Fig. 5.

\section{Visualized Interpretation of at Filed a Suit in the District Court Stage}

As sec. 4, the log-linear parsimonious model for the District Court review judgment stage was inputted into SPSS to output an MCA map; naming principles for dimensions 1 and 2 are based on the discrimination measures of maximum plaintiff PLT $=0.627$ and court location $\mathrm{CL}=0.581$, as shown in Table 14.

The MCA map inertia (explanatory power) of the District Court review and judgment stage was reached $55 \%$, as shown in Table 15.

In the resolution results of the log-linear model shown on a two-dimensional plane, payment-type cases were generally small claims cases brought by contractors, of which most were

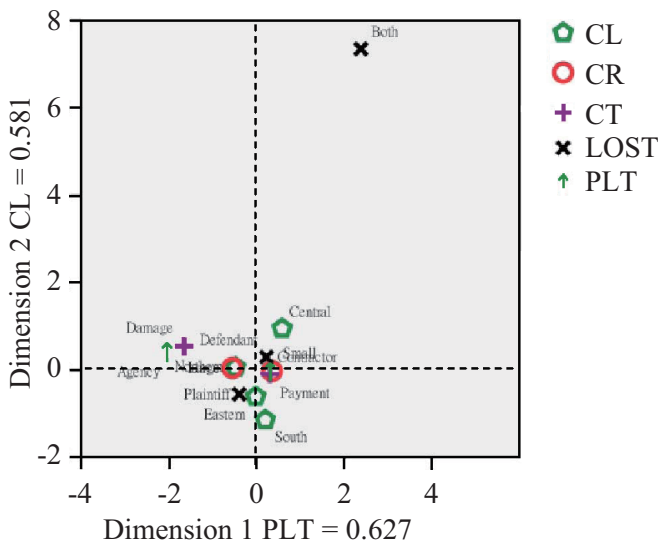

Fig. 6. District court review stage MCA map.

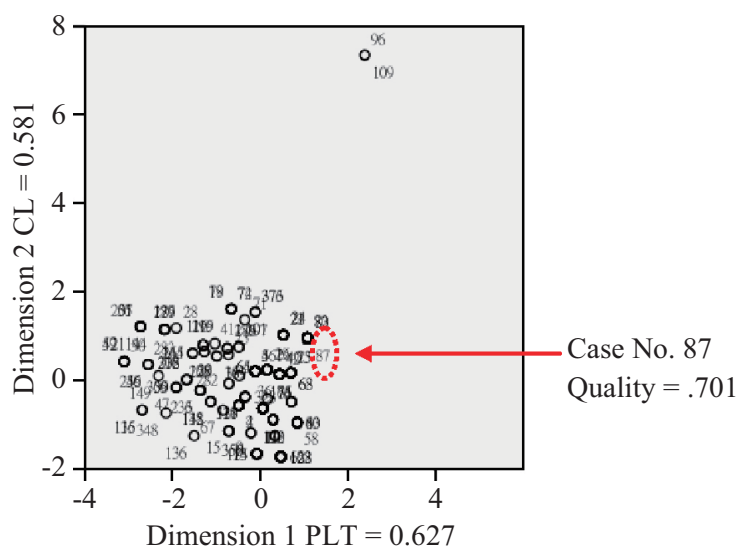

Fig. 7. Objective sampling for examination of district court review stage cases.

lost by the agency in question; compensation types were generally large claim cases brought by agencies, of which most were lost by the plaintiff agency. First Instance cases in which both sides lost were considered outliers as shown in Fig. 6 .

Of 400 specific cases in the litigation preparation stage, the contribution of dimension to inertia of point outputted by SPSS software ("Quality") was calculated to have a mean of 0.32 and a SD of 0.26 ; a degree was constituted by the mean plus $1 \mathrm{SD}$. There were 93 cases with high explanatory power, as demonstrated by their Quality being higher than 0.58 . These cases can provide an objective basis for sampling in research on cases in district court review and judgment, as shown in Fig. 7.

\section{CONCLUSIONS AND SUGGESTIONS}

The paper spanned 10 years, from 1999 to 2008, and included public data of legal proceedings crossing the date of implementation of the Government Procurement Law. Through log-linear analysis, this study examined First Instance litigation judgment association variables, augmented by multiple 
correspondence analysis, to convert judgment documents of over 4 million words into a two-dimensional figure, providing a visualized aid for resolution. At the same time, study result also identified specific cases for future research, filling the vacuum left by previous micro-perspective research, which could not meet the requirements of statistical tests. The primary findings of this study included: (1) the GPL contributed to shortening litigation time; litigation that took place after implementation of the GPL was 1.63 times shorter than litigation that occurred before; (2) professional engineering agencies were $51 \%$ more likely to become involved in litigation compared to non-engineering professional agencies; (3) in public works payment-type and damage compensation-type civil litigation, Second Instance cases in which contractors lost upheld $52.38 \%$ of First Instance cases, this First Instance upholding rate appears to be trending lower than the 2008 statistics published by the Judicial Yuan [25]; (4) There were differences in judgment between northern, central, and southern District Courts; in northern District Courts, the odds ratio for agencies losing First Instances was approximately 1.85 times that for contractors losing, and the First Instance affirmed by High Court was $64.91 \%$; in the central area, the odds ratio was approximately 1.39 times greater than that for contractors, and the First Instance affirmed by High Court was $58.16 \%$; in the southern area, agencies had an advantage over contractors with an odds ratio of approximately 0.54 times, and the First Instance affirmed by High Court was only $35.06 \%$; (5) in 400 specific cases, the contribution of vectors to points - "Quality" was defined as a mean plus $1 \mathrm{SD}$, meaning that the 30 cases which were greater than or equal to 0.75 provided an objective basis for case study materials; (6) categorical analysis seems to be feasible for use in data simplification analysis of complex engineering legal affairs.

The initial examination results of this study can be continued by the correlated variables of the Second Instance litigation stage, echoing the assertion that engineering legal affairs problems lie in the synergistic expectations of effectiveness and efficiency.

\section{REFERENCES}

1. Abdi, H. and Valentin, D., Multiple Correspondence Analysis: Encyclopedia of Measurement and Statistics, Sage, Thousand Oaks, CA, pp. 651-657 (2007).

2. Agresti, A., Categorical Data Analysis, John Wiley \& Sons, N. J., pp. 80-82 (2002).

3. Agresti, A., Categorical Data Analysis, second edition, John Wiley \& Sons, N. J., p. 205 (2007).

4. Agresti, A. and Finlay, B., Statistical Methods for the Social Sciences, Pearson Prentice Hall, N. J., pp. 470-480 (2009).

5. Barrie, D. S. and Paulson, B. C., Professional Construction Management, McGraw-Hill, New York, pp. 470-474 (1992).

6. Beard, J. L., Loulakis, M. C., and Wundram, E. C., Design Build Planning Through Development, McGraw-Hill, New York, pp. 469-471 (2001).

7. Cheeks, J. R., "Multistep dispute resolution in design and construction industry," ASCE Journal of Professional Issues in Engineering Education and Practice, Vol. 129, No. 2, pp. 84-91 (2003).

8. Cheung, S. O., "Critical factors affecting the use of alternative dispute resolution processes in construction," International Journal of Project Management, Vol. 17, No. 3, pp. 189-194 (1999).

9. Cheung, S. O., Suen, C. H., and Lam T. I., "Fundamentals of alternative dispute resolution processes in construction," ASCE Journal of Construction Engineering and Management, Vol. 128, No. 5, pp. 409-417 (2002).

10. Clausen, S. E., Applied Correspondence Analysis: An Introduction, SAGE, London, pp. 43-46 (1998)

11. Clausen, S. E., Applied Correspondence Analysis: An Introduction, SAGE, London, pp. 5-8 (1998).

12. Clough, R. H., Sears, G. A., and Sears, S. K., Construction Project Management, Wiley, New York, pp. 251-253 (2000).

13. Cushman, R. F. and Myers, J. J., Construction Law Handbook, Vol. 1, Aspen Law \& Business, New York, pp. 283-285 (1999).

14. Diekmann, J. E. and Nelson, M. C., "Construction claims: frequency and severity," ASCE Journal of Construction Engineering and Management, Vol. 111, No. 1, pp. 74-81 (1985).

15. Gibbs, K. C. and Gordon, H., California Construction Law, Aspen Publishers, New York, pp. 481-483 (2000).

16. Gnaedinger, J. P., "It's time for some changes," ASCE Journal of Performance of Constructed Facilities, Vol. 2, No. 4, pp. 199-208 (1988).

17. Greenacre, M. J., Theory and Applications of Correspondence Analysis, Academic Press, University of South Africa, Pretoria, pp. 14-41 (1984).

18. Greenacre, M. J. and Blasius, J., Multiple Correspondence Analysis and Related Methods, Taylor \& Francis Group, Baca Raton, pp. 4-21 (2006).

19. Guo, X., Study on Quality Evaluation of Public Works Design and Planning, Master Thesis, Department of Architecture, National Cheng Kung University, Tainan, Taiwan, pp. 21-22 (2006). (in Chinese)

20. Harmon, K. M. J., "Conflicts between owner and contractors: proposed intervention process," ASCE Journal of Management in Engineering, Vol. 19, No. 3, pp. 121-125 (2003).

21. Hohns, H. M., Preventing and Solving Construction Contract Disputes, Van Nostrand Reinhold, New York, pp. 6-10 (1979).

22. Holsti, O. R., Content Analysis for the Social Science and Humanities, Addison-Wesley, Reading, MA, pp. 24-25 (1969).

23. Jahren, C. T. and Dammeier, B. F., "Investigation into construction disputes," ASCE Journal of Management in Engineering, Vol. 6, No. 1, pp. 39-46 (1990).

24. Jannadia, M. O., Assaf, S. A., Bubshait, A., and Naji, A., "Contractual methods for dispute avoidance and resolution (DAR)," International Journal of Project Management, Vol. 18, pp. 41-49 (2000).

25. Judicial Yuan, Judicial Weekly, Vol. 1436, http://www.judicial.gov.tw/ jw9706/pdf/1436-1.pdf (2009). (in Chinese)

26. Judicial Yuan, "Structure and functions of the Judicial Yuan website," http://www.judicial.gov.tw/en/ (2009).

27. Knoke, D. and Burke, P. J., Log-Linear Models, Sage, CA, pp. 30-32 (1980).

28. Lee and Li, Attorneys-at-Law, Sources and Problems of Government Procurement Disputes Categories Analysis, Research Report, Public Construction Commission Executive Yuan (2003). (in Chinese)

29. Lee and Li, Attorneys-at-Law, Damage Obligation of Contractor of Government Procurement Disputes, Research Report, Public Construction Commission Executive Yuan (2006). (in Chinese)

30. PCL Tran Asia Law Offices, Frequency Litigation Disputes Categories of Public Works Agencies, Research Report, Public Construction Commission Executive Yuan (2002). (in Chinese)

31. Public Administration Program, Log-Linear Models: Statnotes, North Carolina State University, http://faculty.chass.ncsu.edu/garson/PA765/ logit.htm.

32. Public Construction Commission Executive Yuan, Construction Procurement Contract Administration, Government Publication, (2008). (in Chinese)

33. Qiu, C. C., New Debt General Chapter of Civil Law, Vol. 1, Fu Jen Catholic University, Taipei, pp. $42-47$ (2003). (in Chinese)

34. Sanvido, V. G., Francois, P. K., Guvenis, M., and Coyle, M., "Critical success factors for construction projects," ASCE Journal of Construction 
Engineering and Management, Vol. 118, No. 1, pp. 94-111 (1992).

35. SPSS, Advanced Statistics 6.1, SPSS Inc., Chicago, pp. 145-164 (1994).

36. SPSS, Categories 6.1, SPSS Inc., Chicago, pp. 49-63 (1994).

37. Steen, R. H., "Five steps to resolving construction disputes without litigation," ASCE Journal of Management in Engineering, Vol. 10, No. 41, pp. 19-23 (1994)

38. Torone, B., "Winning ADR battle," ASCE Journal of Management in Engineering," Vol. 14, No. 5, pp. 32-34 (1998).

39. Williamson, O. E., Markets and Hierarchies, Analysis and Antitrust
Implications: A Study in the Economics of Internal Organization, Free Press, New York, pp. 26-29 (1975).

40. Williamson, O. E., "Transaction cost economics: The governance of contractual relations," Journal of Law and Economics, Vol. 22, pp. 223261 (1979).

41. Wu, H. S., Li, C. C., and Lee, J. R., "Public work's civil litigation analysis in Taiwan," The 11th Symposium on Construction and Management on Project Procurement and Disputes Resolution, Taiwan, pp. $71-77$ (2007). (in Chinese) 